\title{
Meningitis associated with sulphasalazine in a patient with Sjögren's syndrome and polyarthritis
}

\author{
P Merrin, I A Williams
}

\begin{abstract}
A case of meningitis occurring in a 37 year old woman with Sjögren's syndrome, seropositive arthritis, and a possible overlap syndrome soon after starting sulphasalazine and after subsequent rechallenge is reported.
\end{abstract}

\section{Case report}

Our patient, a 37 year old white woman with Sjögren's syndrome confirmed by labial biopsy, was first seen in 1985. At that time she had positive rheumatoid and antinuclear factors of low titre but had no clinical evidence of an inflammatory arthropathy. Vitiligo was noted but there was no evidence of Raynaud's phenomenon.

In early 1987 she developed joint pains with clinical evidence of an active, mild polyarthritis but without nodules or vasculitic lesions. Rheumatoid factor was positive to high titre (1/2560); thyroid antibodies were positive; antinuclear factor 1/40; anti-dsDNA was negative. Subsequent investigation showed hypothyroidism, which responded to thyroxine. Radiographs of her hands showed no erosive changes.

In late 1987 her polyarthritis became active, particularly affecting the small joints of the hands. As non-steroidal anti-inflammatory drugs failed to give relief treatment was started with intramuscular gold, $50 \mathrm{mg}$ weekly, and she was given a pulse $(1 \mathrm{~g})$ of methylprednisolone. After a total dose of $460 \mathrm{mg}$ of gold she developed stomatitis, which rapidly remitted when the drug was stopped. Gold was restarted but at a lower weekly dose of $20 \mathrm{mg}$ intramuscularly. She subsequently developed recurrent boils, and after a total of $1360 \mathrm{mg}$ the drug was withdrawn. An appropriate antibiotic was given, and her skin lesions subsided.

In early 1989 as the arthritis in her joints was still active treatment was started with sulphasalazine $0.5 \mathrm{~g}$ daily for a week then increased to $1.0 \mathrm{~g}$ daily. Three weeks after starting sulphasalazine and taking $1.0 \mathrm{~g}$ daily she was admitted as an emergency with a three day history of severe headache, nausea, and vomiting. She also complained of severe pain in her knees and lower legs.

She had a fever $\left(38^{\circ} \mathrm{C}\right)$, was photophobic, had mild neck stiffness, moderate cervical lymphadenopathy, and a macular rash on her trunk and proximal parts of her limbs. Blood pressure was $110 / 80 \mathrm{mmHg}$. Fundal and general neurological examination results were normal. There was evidence of active arthritis, but her knees were not particularly affected. Straight leg raising was restricted and painful. Her respir- atory, cardiovascular, and alimentary systems were normal.

Investigations gave the following results: haemoglobin $118 \mathrm{~g} / \mathrm{l}$, white blood cell count $11 \cdot 4 \times 10^{9} / 1$ (slight neutrophilia); erythrocyte sedimentation rate $36 \mathrm{~mm} / \mathrm{h}$. Cerebrospinal fluid: white blood cell count $0.64 \times 10^{9} / 1$ (mostly neutrophils), red blood cell count $0.08 \times 10^{9} / 1$, microscopy, no bacteria seen, glucose 3.00 $\mathrm{mmol} / \mathrm{i}$ (plasma glucose $8 \cdot 3 \mathrm{mmol} / \mathrm{l}$ ). Protein was not estimated.

The following results were normal: midstream urine, blood cultures, urea and electrolytes, latex fixation tests, antistreptolysin $\mathrm{O}$ titre, chest radiography, radionuclide bone scan, and viral titres.

Intravenous chloramphenicol, benzylpenicillin, and flucloxacillin seemed to produce rapid improvement in her clinical state, and rash and fever disappeared. Sulphasalazine was discontinued, but she received benorylate as an analgesic. Her knee and lower leg pain persisted for some days. She completed a two week course of the antibiotics. A provisional diagnosis of bacterial meningitis was made, though no definite organism had been isolated.

When seen two weeks after discharge in a routine rheumatology clinic she seemed to have recovered completely, though she felt tired. As her joints were more painful sulphasalazine was restarted. Eight hours after taking $0.5 \mathrm{~g}$ of the drug she became feverish with rigors, a severe headache, rash, and severe pain in her knees and lower legs, the pain causing her more distress than the headache. She was readmitted. Clinical examination showed slight neck rigidity, photophobia, a macular rash on her trunk, limited, painful straight leg raising, but no evidence of a focal neurological lesion.

The results of subsequent investigations were as follows: cerebrospinal fluid: protein $3.9 \mathrm{~g} / \mathrm{l}$, glucose $3.6 \mathrm{mmol} / \mathrm{l}$ (plasma glucose $9 \cdot 1 \mathrm{mmol} / \mathrm{l}$ ), white blood cell count $0.25 \times 10^{9} / 1$ (predominantly neutrophils), red blood cell count $0.01 \times$ $10^{9} / 1$, no organisms were identified and culture was sterile. Haemoglobin concentration was 114 $\mathrm{g} / \mathrm{l}$, white blood cell count $13.6 \times 10^{9} / 1(96 \%$ neutrophils), platelets $403 \times 10^{9} / 1$, erythrocyte sedimentation rate $14 \mathrm{~mm} / \mathrm{h}$, antistaphylolysin and nuclease titres were normal, chest radiograph and computed tomographic brain scan were normal. Results of other routine investigations were normal.

She was given antibiotics and analgesics intravenously, but her response was slow. After 48 hours and a general review of the possible causes it was suggested that both episodes of meningitis might have been due to a hyper- 
sensitivity reaction to sulphasalazine. Antibiotics were discontinued and she was given intravenous hydrocortisone $200 \mathrm{mg}$ six hourly. Within 24 hours there was marked clinical improvement. Her drugs were then changed to oral prednisolone $15 \mathrm{mg}$ daily, and she continued to improve. Three days after starting corticosteroids a lumbar puncture was repeated. Cerebrospinal fluid results were: protein $0.74 \mathrm{~g} / \mathrm{l}$, glucose $5 \cdot 1 \mathrm{mmol} / 1$, white blood cell count $0.05 \times 10^{9} / 1$ (70\% lymphocytes, $25 \%$ neutrophils), culture was sterile.

Further serological results were as follows: DNA binding antibodies $3.3 \mathrm{IU} / \mathrm{ml}$ (normal $<7)$; Crithidia DNA immunofluorescence: positive, Crithidia DNA IgM >320; extractable nuclear antigen antibodies: positive-RNP: negative, SSB(La) and (Ro): positive, Sm: negative; antinuclear antibodies-IgM 1/320, IgG 1/320, pattern: diffuse; anticardiolipin IgG and IgM negative. As yet we do not know her immunogenetic status.

Three months after discharge she remains well but continues to take $2.5 \mathrm{mg}$ of prednisolone daily. So far her arthritis seems to be nonerosive without nodule formation or obvious vasculitis.

\section{Discussion}

There seems little doubt that the two episodes of meningitis in this patient were aseptic and hypersensitivity reactions to sulphasalazine.

The more common toxic effects of sulphasalazine are well reported, commonly affecting the gastrointestinal tract; neurotoxicity is a rarely reported complication. Wallace records a case of ataxia with incoordination of both legs with impairment of all modes of sensation from the waist down in a patient with ulcerative colitis who had received the drug for only one month in doses up to $3 \mathrm{~g}$ daily. ${ }^{1}$ Smith and his colleagues reported two patients with ulcerative colitis who developed combined hepatotoxicity and neurotoxicity within three weeks of starting sulphasalazine and when taking $3 \mathrm{~g}$ daily. ${ }^{2}$ One patient developed confusion and neck stiffness after being rechallenged with the drug, the other, confusion, hallucinations, and two grand mal seizures. Only the latter patient had a lumbar puncture and cerebrospinal fluid examination, which gave normal results. All these patients made complete recoveries on withdrawal of sulphasalazine.

The severe non-articular pain experienced by our patient in her knees and lower legs coupled with restriction of straight leg raising suggests cauda equina involvement, presumably by meningeal irritation. Meningitis with cerebrospinal fluid changes has been seen in a patient with systemic lupus erythematosus after taking ibuprofen, ${ }^{3}$ and the cauda equina syndrome has been reported in patients with high titres of RNP antibodies. ${ }^{4}$

Whether the reaction of our patient to sulphasalazine was uncomplicated, or perhaps mediated by her immunological dysfunction, is unclear. Reports suggest that systemic lupus erythematosus and Sjögren's syndrome are associated with an increased frequency of drug reactions. ${ }^{5-8}$ Although at onset Sjögren's syndrome was the most appropriate diagnosis, the development of a severe polyarthritis and a high titre of rheumatoid factor suggested an associated rheumatoid arthritis. The non-erosive character of the arthritis coupled with the results of the recent antibody screen favour the original diagnosis, however.

Whether the recent finding of positive antibodies to Crithidia indicates that our patient may now conform to the subset of 'Sjögren's associated overlap syndrome', as classified by Maini, ${ }^{9}$ or that sulphasalazine might have produced a 'systemic lupus erythematosus-like' reaction in a previously uncomplicated case of Sjögren's syndrome, are two other interesting possibilities.

As sulphasalazine is becoming more popular as a disease modifying agent in the treatment of rheumatoid arthritis the possibility of neurotoxicity or meningitis occurring within the first few weeks of starting the drug should be kept in mind.

1 Wallace M B. Neurotoxicity associated with a reaction to sulphasalazine. Practitioner 1970; 204: 850-1.

2 Smith M D, Gibson G E, Rowland R. Combined hepatotoxicity and neurotoxicity following sulphasalazine admintoxicity and neurotoxicity following sulphas

3 Widener $\mathbf{H}$ L, Bruce H, Littman M D. Ibuprofen-induced meningitis in systemic lupus erythematosus. $\mathcal{F A M A} 1978$ 239: $1062-4$.

4 Kappes J, Bennett $M$. Cauda equina syndrome in a patient with a high titre anti-RNP antibodies. Arthritis Rheum 1982; 25: 349-52.

5 Goldman J A, Klimek G A, Ali R. Allergy in systemic lupus erythematosus. Arthritis Rhewm 1976; 19: 669-76.

6 Becker L C. Allergy in systemic lupus erythematosus. Fohns Hopkins Medical foumal 1973; 133: 38-44.

7 Von Maur K, Turk A, Stevens M B, et al. Lack of increased hypersensitivity to penicillin in patients with systemic lupus erythematosus [Abstract]. f Allergy Clin Immunol lupus erythem

8 Bloch K J, Buchanan W W, Wohl M J, et al. Sjögren's syndrome. A clinical, pathological, and serological study of sixty-two cases. Medicine (Baltimore) 1965; 44: 187-231.

9 Maini R N, Talal N, Moutsopoulos H M, Kassan S S. The relationship of Sjögren's syndrome to rheumatoid arthritis. In: Sjögren's syndrome: clinical and immunological aspects. Berlin: Springer, 1987: 165-76. 